$\begin{array}{ll}\text { Research Square } & \text { Preprints are preliminary reports that have not undergone peer review. } \\ \text { They should not be considered conclusive, used to inform clinical practice, } \\ \text { or referenced by the media as validated information. }\end{array}$

\title{
Synergistic Effect of Genetic Polymorphisms in TLR6 and TLR10 Genes on The Risk of Pulmonary Tuberculosis in Moldavian Population
}

Alexander Varzari ( $\sim$ alexander.varzari@mail.ru )

Chiril Draganiuc Institute of Phthisiopneumology

Igor V. Deyneko

Russian State Agrarian University Moscow Timiryazev Agricultural Academy: Rossijskij gosudarstvennyj agrarnyj universitet MSHA imeni K A Timirazeva

Elena Tudor

Chiril Draganiuc Institute of Phthisiopneumology

Harald Grallert

Helmholtz Zentrum München Deutsches Forschungszentrum für Umwelt und Gesundheit: Helmholtz Zentrum Munchen Deutsches Forschungszentrum fur Gesundheit und Umwelt

Thomas Illig

Hannover Medical School: Medizinische Hochschule Hannover

\section{Research article}

Keywords: Tuberculosis, Host genetics, Candidate genes, Immunity, Polymorphism, Susceptibility

Posted Date: October 19th, 2020

DOI: https://doi.org/10.21203/rs.3.rs-90882/v1

License: @ (i) This work is licensed under a Creative Commons Attribution 4.0 International License. Read Full License

Version of Record: A version of this preprint was published at Innate Immunity on July 18th, 2021. See the published version at https://doi.org/10.1177/17534259211029996. 


\section{Abstract}

BACKGROUND: Host immunity is essential for efficient recognition and clearance of $M$. tuberculosis infection. Polymorphisms in genes that regulate immune response have been reported to influence the susceptibility/resistance to pulmonary tuberculosis (TB). Here we evaluated associations between 14 polymorphisms in 12 core genes involved in immune responses and pulmonary TB in Moldavian population, and investigated whether interactions between these and previously analyzed polymorphisms could exist and modulate the risk of pulmonary TB.

METHODS: Polymorphisms VDR rs7975232, VDR rs1544410, VDR rs2228570, MR1 rs1052632, TLR1 rs5743618, TLR2 rs111200466, TLR10 rs11096957, SLC11A1 rs2276631, IL 1B rs1143643, IL 10 rs1800896, IFNG rs2430561, TNF rs1800629, IRAK1 rs1059703, and FOXP3 rs2232365 were genotyped in 271 Moldavian pulmonary TB cases and 251 community-matched healthy controls. Associations were tested using Fisher test and logistic regression. Complemented with the data from our previous study (PMID: 30529560), investigation of gene-gene interactions was performed for a total of 43 loci. Significance level was adjusted by the Bonferroni correction.

RESULTS: Single polymorphism analysis revealed a nominal association between TNFrs1800629 and pulmonary TB (Fisher exact test $p$-value $=0.01843$ ). Marginal differences between cases and controls were observed for haplotypes in the gene cluster TLR1-TLR6-TLR10 and gene TLR2. In the pairwise interaction analysis, the combination of genotypes TLR6 rs5743810 GA and TLR10 rs11096957 GT was significantly associated with an increased genetic risk of pulmonary TB $\left(\mathrm{OR}=2.48,95 \% \mathrm{Cl}=1.62-3.85\right.$; Fisher exact test $p$-value $=1.5 \times 10^{-5}$, significant after Bonferroni correction $)$.

CONCLUSION: The TLR6 rs5743810 and TLR10 rs11096957 two-locus interaction confers a significantly higher risk for pulmonary TB and has potential as a novel biomarker for predicting TB susceptibility.

\section{Introduction}

Tuberculosis (TB), caused by the bacillus Mycobacterium tuberculosis (M.tb), is a major cause of morbidity and mortality in many developing countries and a significant threat to health in the developed world. One-third of the world's population is infected with M.tb, but only a minor fraction of those ( 5-10\%) develops the active form of the disease [1]. Although several environmental and clinical conditions, such as diabetes mellitus, malnutrition, alcohol abuse, smoking, age, AIDS and immunosuppressive therapies, are known to promote the development of the disease, many TB patients have no above mentioned or other obvious risk factors. Evidence from animal and human studies indicates the importance of host genetic factors in the development of TB [2].

To date a considerable number of genetic candidates for TB susceptibility have been detected and characterized across populations by means of candidate gene approaches and genome wide association studies [3,4]. Particular interest was focused on genetic factors of the immunoinflammatory response modulating infectivity and progression of infection, including Toll-like receptors (TLR1-TLR10), the natural resistance-associated macrophage protein (NRAMP1; also called as solute carrier 11a1, SLC11A1), vitamin-D receptor (VDR), cytokines tumor necrosis factor alpha (TNF), interleukin 1 (IL 1B), interferon-Y (IFNG), and interleukin 10 (IL 10). Polymorphisms in these and other genes involved in immune response have been reported to be associated with TB in different populations, although results were inconsistent $[3,4,5]$.

We have earlier evaluated the effect of common genetic variations in TLR pathway on the risk of pulmonary TB in Moldavian population and identified variants in TLR2, TLR8 and TLR9 as being associated with TB [6]. In the present work, we extended the analysis to 14 additional polymorphisms from 12 TB immune response candidate genes and investigated all pairwise genetic interactions for these and the previous genetic variants (altogether 43 polymorphisms). Selected polymorphisms for this study have previously been shown to change the level or function of corresponding gene products and to influence susceptibility/resistance to infections (Table 1). 
Table 1

Candidate genes and polymorphisms that are of interest in the present study.

\begin{tabular}{|c|c|c|c|c|c|c|c|c|c|}
\hline Gene & Locus & Protein & Gene class & $\begin{array}{l}\text { Protein } \\
\text { function }\end{array}$ & Polymorphism & $\begin{array}{l}\text { Nucleotide } \\
\text { substitution }\end{array}$ & Location & $\begin{array}{l}\text { Frequency } \\
\text { a }\end{array}$ & Ref. \\
\hline TLR1 & $4 p 14$ & $\begin{array}{l}\text { Toll-like receptor } \\
1\end{array}$ & $\begin{array}{l}\text { Pattern } \\
\text { recognition } \\
\text { receptor }\end{array}$ & $\begin{array}{l}\text { Recognizes } \\
\text { bacterial } \\
\text { lipopeptides, } \\
\text { activates } \\
\text { macrophages } \\
\text { and initiates } \\
\text { immune } \\
\text { response }\end{array}$ & rs5743618 & $C>A$ & $\begin{array}{l}\text { Missense } \\
\text { (p.Ser602lle) }\end{array}$ & $\begin{array}{l}0.172- \\
0.500\end{array}$ & $\begin{array}{l}{[7,8]} \\
\text { Uciechov } \\
2011 ; \\
\text { Naderi et } \\
2016\end{array}$ \\
\hline$T L R 2$ & $4 q 31.3$ & $\begin{array}{l}\text { Toll-like receptor } \\
2\end{array}$ & $\begin{array}{l}\text { Pattern } \\
\text { recognition } \\
\text { receptor }\end{array}$ & $\begin{array}{l}\text { Recognizes } \\
\text { bacterial } \\
\text { lipopeptides, } \\
\text { activates } \\
\text { macrophages } \\
\text { and initiates } \\
\text { immune } \\
\text { response }\end{array}$ & rs111200466 & $23 \mathrm{bp}$ del & 5' UTR & $\begin{array}{l}0.116- \\
0.172\end{array}$ & $\begin{array}{l}\text { [9] Velez } \\
\text { al. } 2010\end{array}$ \\
\hline TLR10 & $4 p 14$ & $\begin{array}{l}\text { Toll-like receptor } \\
10\end{array}$ & $\begin{array}{l}\text { Pattern } \\
\text { recognition } \\
\text { receptor }\end{array}$ & $\begin{array}{l}\text { Recognizes } \\
\text { bacterial } \\
\text { ligands, } \\
\text { activates } \\
\text { macrophages } \\
\text { and initiates } \\
\text { immune } \\
\text { response }\end{array}$ & rs11096957 & $\mathrm{T}>\mathrm{G}$ & $\begin{array}{l}\text { Missense } \\
\text { (p.Asn241His) }\end{array}$ & $\begin{array}{l}0.324- \\
0.486\end{array}$ & $\begin{array}{l}{[10,11]} \\
\text { Oosting ‘ } \\
\text { al. 2014; } \\
\text { Bulat- } \\
\text { Kardum ' } \\
\text { al. } 2015\end{array}$ \\
\hline IRAK1 & Xq28 & $\begin{array}{l}\text { Interleukin-1 } \\
\text { receptor- } \\
\text { associated kinase } \\
1\end{array}$ & $\begin{array}{l}\text { Serine/ } \\
\text { threonine } \\
\text { kinase }\end{array}$ & $\begin{array}{l}\text { Regulates } \\
\text { TLR and IL- } \\
\text { 1R mediated } \\
\text { signaling }\end{array}$ & rs1059703 & $G>A$ & $\begin{array}{l}\text { Missense } \\
\text { (p.Ser532Leu) }\end{array}$ & $\begin{array}{l}0.088- \\
0.211\end{array}$ & $\begin{array}{l}{[12,13]} \\
\text { Sampath } \\
\text { al. 2013; } \\
\text { et al. 201 }\end{array}$ \\
\hline IFNG & $12 q 15$ & $\begin{array}{l}\text { Interferon-y (IFN- } \\
\text { Y) }\end{array}$ & Cytokine & $\begin{array}{l}\text { Activates } \\
\text { macrophages } \\
\text { to eliminate } \\
\text { intracellular } \\
\text { pathogens, } \\
\text { including Mtb }\end{array}$ & rs2430561 & $A>T$ & Intron & $\begin{array}{l}0.354- \\
0.528\end{array}$ & $\begin{array}{l}{[14,15]} \\
\text { Pravica } \epsilon \\
\text { al. 2000; } \\
\text { Wei et al. } \\
2017\end{array}$ \\
\hline$T N F$ & $6 p 21.3$ & $\begin{array}{l}\text { Tumor necrosis } \\
\text { factor alpha } \\
\text { (TNF-a) }\end{array}$ & Cytokine & $\begin{array}{l}\text { Activates } \\
\text { macrophages } \\
\text { to eliminate } \\
\text { intracellular } \\
\text { pathogens, } \\
\text { attracts } \\
\text { immunity } \\
\text { cells to the } \\
\text { site of } \\
\text { infection }\end{array}$ & rs1800629 & $G>A$ & Promoter & $\begin{array}{l}0.094- \\
0.187\end{array}$ & $\begin{array}{l}\text { [16, 17, } 1 \\
\text { Elahi et a } \\
2009 ; \\
\text { Correa et } \\
\text { 2005; de } \\
\text { Arellano } \\
\text { al. 2020 }\end{array}$ \\
\hline$I L 1 B$ & $2 q 14.1$ & $\begin{array}{l}\text { Interleukin } 1 \text { beta } \\
(\text { IL-1 } \beta)\end{array}$ & Cytokine & $\begin{array}{l}\text { Activates T- } \\
\text { cells and } \\
\text { promotes the } \\
\text { production of } \\
\text { IFN-y }\end{array}$ & rs1143643 & $C>T$ & Intron & $\begin{array}{l}0.286- \\
0.388\end{array}$ & $\begin{array}{l}\text { [19] Hall } \\
\text { al. } 2015\end{array}$ \\
\hline IL 10 & $1 q 32.1$ & $\begin{array}{l}\text { Interleukin } 10 \text { (IL- } \\
\text { 10) }\end{array}$ & Cytokine & $\begin{array}{l}\text { Inhibits IFN-y } \\
\text { production } \\
\text { and MHC } \\
\text { class II } \\
\text { expression } \\
\text { on } \\
\text { macrophages }\end{array}$ & rs1800896 & $A>G$ & Promoter & $\begin{array}{l}0.456- \\
0.601\end{array}$ & $\begin{array}{l}{[20,21]} \\
\text { Turner et } \\
\text { 1997; } \\
\text { Areeshi } \epsilon \\
\text { al. 2017 }\end{array}$ \\
\hline SLC11A1 & $2 q 35$ & $\begin{array}{l}\text { Natural } \\
\text { Resistance- } \\
\text { Associated } \\
\text { Macrophage } \\
\text { Protein } 1\end{array}$ & $\begin{array}{l}\text { Metal ion } \\
\text { transporter }\end{array}$ & $\begin{array}{l}\text { Influences } \\
\text { Mtb survival } \\
\text { by regulating } \\
\text { cation levels } \\
\text { in the } \\
\text { macrophage }\end{array}$ & rs2276631 & $C>T$ & Synonymous & $\begin{array}{l}0.202- \\
0.332\end{array}$ & $\begin{array}{l}{[22,23]} \\
\text { Freĭdin et } \\
\text { 2006; Yu } \\
\text { et al. } 201\end{array}$ \\
\hline
\end{tabular}

a Allele frequency range in European populations (CEU, FIN, GBR, IBS, TSI) according to 1000 Genomes (http://www.1000genomes.org); minor allele in CEU w used as the reference. Minor allele in CEU population is underlined.

SNP rs2276631 in SLC11A1 is non-functionmal (synonymous) variant, which is in strong LD with the nearby TB associated SNP rs3731865 (INT4) (D' = 0.97 and $r^{2}=0.9479$ in European populations). 


\begin{tabular}{|c|c|c|c|c|c|c|c|c|c|}
\hline Gene & Locus & Protein & Gene class & $\begin{array}{l}\text { Protein } \\
\text { function }\end{array}$ & Polymorphism & $\begin{array}{l}\text { Nucleotide } \\
\text { substitution }\end{array}$ & Location & $\begin{array}{l}\text { Frequency } \\
\text { a }\end{array}$ & Ref. \\
\hline FOXP3 & Xp11.23 & $\begin{array}{l}\text { Forkhead box } \\
\text { protein P3 } \\
\text { (FoxP3) }\end{array}$ & $\begin{array}{l}\text { Transcriptional } \\
\text { regulator }\end{array}$ & $\begin{array}{l}\text { Inhibits } \\
\text { cytokine } \\
\text { production } \\
\text { (IFN-y) and T- } \\
\text { cell effector } \\
\text { function }\end{array}$ & rs2232365 & $\mathrm{T}>\mathrm{C}$ & Intron & $\begin{array}{l}0.338- \\
0.450\end{array}$ & $\begin{array}{l}\text { [24] } \\
\text { Beiranva } \\
\text { et al. } 201\end{array}$ \\
\hline \multirow[t]{3}{*}{$V D R$} & \multirow[t]{3}{*}{$12 q 13.11$} & \multirow[t]{3}{*}{$\begin{array}{l}\text { Vitamin D } \\
\text { receptor }\end{array}$} & \multirow[t]{3}{*}{$\begin{array}{l}\text { Ligand } \\
\text { activated } \\
\text { transcription } \\
\text { factor }\end{array}$} & \multirow[t]{3}{*}{$\begin{array}{l}\text { Regulates } \\
\text { expression of } \\
\text { a number of } \\
\text { genes } \\
\text { involved in } \\
\text { killing of Mtb }\end{array}$} & rs7975232 & $C>A$ & Intron & $\begin{array}{l}0.404- \\
0.539\end{array}$ & $\begin{array}{l}{[25,26]} \\
\text { Uitterlind } \\
\text { et al. 20C } \\
\text { Xu and } \\
\text { Shen 201 }\end{array}$ \\
\hline & & & & & rs1544410 & $C>T$ & Intron & $\begin{array}{l}0.338- \\
0.470\end{array}$ & $\begin{array}{l}\text { [25, 26, } 2 \\
\text { Uitterlind } \\
\text { et al. 20C } \\
\text { Chen et a } \\
\text { 2013; Xu } \\
\text { and Sher } \\
2019\end{array}$ \\
\hline & & & & & rs2228570 & $A>G$ & $\begin{array}{l}\text { Missense } \\
\text { (p.Met1Thr) }\end{array}$ & $\begin{array}{l}0.327- \\
0.429\end{array}$ & $\begin{array}{l}\text { [25, 26, } 2 \\
\text { Uitterlind } \\
\text { et al. 20C } \\
\text { Chen et a } \\
\text { 2013; Xu } \\
\text { and Sher } \\
2019\end{array}$ \\
\hline MR1 & $1 q 25.3$ & $\begin{array}{l}\text { Major } \\
\text { histocompatibility } \\
\text { complex class I- } \\
\text { related gene } \\
\text { protein }\end{array}$ & $\begin{array}{l}\text { Antigen- } \\
\text { presenting } \\
\text { molecule }\end{array}$ & $\begin{array}{l}\text { Presents } \\
\text { metabolites } \\
\text { of microbial } \\
\text { vitamin B to } \\
\text { MAITs }\end{array}$ & rs1052632 & $\mathrm{G}>\mathrm{A}$ & Intron & $\begin{array}{l}0.266- \\
0.303\end{array}$ & $\begin{array}{l}\text { [28] } \\
\text { Seshadri } \\
\text { al. } 2017\end{array}$ \\
\hline
\end{tabular}

a Allele frequency range in European populations (CEU, FIN, GBR, IBS, TSI) according to 1000 Genomes (http://www.1000genomes.org); minor allele in CEU w used as the reference. Minor allele in CEU population is underlined.

SNP rs2276631 in SLC11A1 is non-functionmal (synonymous) variant, which is in strong LD with the nearby TB associated SNP rs3731865 (INT4) (D' = 0.97 and $r^{2}=0.9479$ in European populations).

The Republic of Moldova is a country with an unfavorable epidemiological situation regarding TB, ranking first for TB incidence (86/100,000 in 2018) in the European region [29]. The identification of host genetic factors may provide a biological and theoretical basis for better understanding the high prevalence of TB within Moldavian population and ultimately for the development of effective TB prevention and control strategies.

\section{Materials And Methods}

\section{Samples}

The investigated case-control cohort included 272 unrelated patients ( 120 women and 152 men; mean age at recruitment $=40.7 \pm 12.7$ years; mean age at diagnosis $=39.1 \pm 12.2$ years) with infiltrative pulmonary TB. The diagnosis was based on clinical symptoms and chest radiographic findings, and confirmed by a bacteriological assessment. None of the patients had a clinical history of diabetes mellitus, HIV infection, or receipt of immunosuppressive therapy. All patients were Caucasians, and predominantly, Moldavians (91.5\%). The control group included 251 unrelated and ethnically matched (Moldavians, 87\%) healthy individuals (150 women and 101 men; mean age at recruitment $=47.6 \pm 14.1$ years), without history of TB and with normal radiographic examination findings. Control group subjects were recruited from the same high burden TB-affected communities as patients. Venous blood samples (EDTA anticoagulant added) were collected from TB patients and controls, and genomic DNA was extracted from peripheral blood leukocytes according to a standard salting-out method (Miller et al. 1988). All the cases and controls were BCG vaccinated, which was confirmed by the presence of a scar in the left shoulder. The study was approved by the Ethics Committee of the Institute of Phthisiopneumology (Republic of Moldova), and the Declaration of Helsinki protocols were followed. Each participant was thoroughly informed and gave written informed consent prior to enrolment in the study.

\section{Polymorphisms selection and genotyping}

The following polymorphisms, VDR rs7975232, VDR rs1544410, VDR rs2228570, MR1 rs1052632, TLR1 rs5743618, TLR2 rs111200466, TLR10 rs11096957, SLC11A1 rs2276631, IL 1B rs1143643, IL 10 rs1800896, IFNG rs2430561, TNF rs1800629, IRAK1 rs1059703, FOXP3 rs2232365 were investigated.

Polymorphisms were selected based on previously published associations with TB, thus increasing the chance of selecting polymorphisms with phenotyping effects (Table 1). All polymorphisms except the insertion/deletion variant rs111200466 in TLR2 (-196 to -174 ins/del) were single nucleotide polymorphisms (SNPs).

Genotypes of the 12 SNPs (VDR rs7975232, VDR rs1544410, VDR rs2228570, MR1 rs1052632, TLR10 rs11096957, SLC11A1 rs2276631, IL 1B rs1143643, IL 10 rs1800896, IFNG rs2430561, TNF rs1800629, IRAK1 rs1059703, FOXP3 rs2232365) were determined with Agena iPlex assays using matrix-assisted laser desorption/ionization time-of-flight (MALDI-TOF) mass array spectrometer (Agena, San Diego, CA) following manufacturer's recommendations. Primers were designed using the Assay Design Suite v2.0 (https://agenacx.com). Two of the SNPs were not in Hardy-Weinberg equilibrium (HWE) in the control group - 
rs11096957 in $T L R 10(p=0.0071)$ and rs2430561 in IFNG ( $p=0.013)$. Genotyping errors were excluded by random re-genotyping of the respective SNPs. Confirmatory genotyping of TLR10 rs11096957 was performed in 52 control samples (21\%) using polymerase chain reaction - restriction fragment length polymorphism (PCR-RFLP). PCR products were digested with the restriction endonuclease N/all (New England Biolabs; Arundel, Australia) and subjected to $2 \%$ agarose gel electrophoresis. Confirmatory genotyping of IFNG rs2430561 was carried out by PCR with sequence-specific primers (SSPs) in 105 control samples (42\%); amplified SNP products were electrophoresed on $2 \%$ agarose gel. All results were $100 \%$ consistent with those generated by MALDI-TOF.

Two polymorphisms TLR1 rs5743618 and TLR2 rs111200466 could not be included in the Agena iPlex assay, and therefore, were genotyped by PCR and PCR - RFLP. Genotyping of rs5743618 was performed using PCR-RFLP. PCR products were digested with the restriction endonuclease Alul (New England Biolabs; Arundel, Australia) and subjected to $2 \%$ agarose gel electrophoresis. Genotyping of rs 111200466 polymorphism was conducted by standard PCR and agarose (2\%) gel electrophoresis.

The primer sequences, PCR conditions and restriction enzymes for genotyping of TLR2 rs111200466, IFNG rs2430561 and TLR1 rs5743618 and TLR10 rs11096957 are outlined in Additional file1: Table S1. The methodology used for the genotyping of TLR2 rs111200466, IFNG rs2430561 and TLR1 rs5743618 polymorphisms has been described elsewhere [14, 31, 32].

\section{Statistical analysis}

Hardy-Weinberg equilibrium (HWE) tests were performed in controls and cases by Fisher exact test. Fisher exact tests were also used for comparison of differences in allele frequencies between groups. Odds ratios (ORs) and 95\% confidence intervals (Cls) were calculated to measure associations between SNPs and the risk of pulmonary TB. Minor alleles were assumed as effect associated alleles in all tests. In addition, logistic regression was used to assess association of each SNP with the risk of pulmonary TB under log-additive genetic model. To account for possible bias due to statistically significant difference in age and sex distributions between case and control groups ( $p<0.0001$ and $p=0.0004$, respectively), the variables age and sex were included as covariates in logistic regression analysis. All genetic tests described above are based on single SNP tests and were performed using PLINK software package (version 1.9, http:// pngu.mgh.harvard.edu/purcell/plink/) [33]. For IRAK1 rs1059703 and FoxP3 rs2232365 SNPs located on X chromosome, HWE p-values were calculated in females only and association tests were performed separately in males and females; therefore 16 tests were conducted in total. To correct significance level for multiple testing, Bonferroni correction was applied, and a significance level for all statistical tests was set at $p<0.003125(0.05 / 16)$.

Haplotype analysis was performed for five polymorphisms in the TLR1-TLR6-TLR10 gene cluster, two polymorphisms in the TLR2 gene and three VDR gene polymorphisms using Haploview version 4.2 software [34]. SNPs TLR1 rs4833095, TLR2 rs3804099, TLR6 rs5743810 and TLR10 rs11466657 were taken from the previous study conducted on the same cohort of TB patients and healthy controls. The Solid spine of the linkage disequilibrium (LD) algorithm was applied to define the haplotype blocks. Differences in haplotype frequencies were tested using $\chi 2$ test. Haplotypes with a frequency below $1 \%$ were excluded from the analyses. Multiple comparisons of haplotype frequencies were corrected by generating empirical p-values via 10,000 permutations.

Pairwise epistatic interactions associated with susceptibility to TB were investigated in two-step approach. In the first step, logistic regression adjusted for sex and age under additive genetic model (implemented in software package SNPstats) was applied to all possible pairwise combinations of the 43 genetic markers from this and our previous study [35]. In total, 1065 (741 common and $2 \times 162$ sex-specific) comparisons were tested. In the second step, all genotype combinations for all significant marker pairs $(p<0.05)$ identified at the first step were analyzed using Fisher exact test and sex and age adjusted logistic regression $[36,37]$. To account for multiple testing, we used Bonferroni correction and counted all tests of the first and second steps as independent, yielding a multiplication factor of $1 /(1065+543)=0.000622$.

Power analysis was performed using CaTS [38] with a log-additive genetic model, assuming significance (type I error) of 0.05 and the reported TB disease prevalence of 0.0025 [29]. The present study provides sufficient power $(>80 \%)$ to detect minimum ORs of 2.0 and 1.5 for high-risk allele frequencies of $>0.05$ and $>0.20$, respectively.

\section{Results \\ Single polymorphism analysis}

Distributions of alleles of the investigated SNPs were in accordance with HWE in both groups except for TLR10 rs11096957 (Additional file 2: Table S2), which showed some deviation from HWE in controls $(p=0.0078)$. The MAFs of all the polymorphisms in our controls were similar to those in the populations of European descent from the 1000 Genomes Project database (Table 2). Association analysis between individual SNPs and TB revealed an evidence for moderate association between rs1800629 in TNF and pulmonary TB risk (Fisher exact test: OR =0.63, $p$-value $=0.01843$; logistic regression: OR $=0.64, p$-value $=0.03643$ ) (Table 1), which did not remain significant after Bonferroni correction for multiple testing $(p$-value $>0.003125)$. None of the other studied loci showed associations with pulmonary TB risk (Table 2). 
Table 2

Association analysis of individual polymorphisms with TB risk. For genotype data, see Supplementary Table 2.

\begin{tabular}{|c|c|c|c|c|c|c|c|}
\hline Polymorphism & Major/Minor allele & MAF in controls & MAF in patients & \multicolumn{2}{|c|}{ Fisher exact test } & \multicolumn{2}{|c|}{ Logistic regression a } \\
\hline \multicolumn{8}{|l|}{ Both sexes } \\
\hline VDR rs7975232 & $\mathrm{C} / \mathrm{A}$ & 0.481 & 0.509 & 0.3797 & $1.12(0.87-1.43)$ & 0.1819 & $1.20(0.92-1.57)$ \\
\hline VDR rs 1544410 & $\mathrm{C} / \mathrm{T}$ & 0.379 & 0.374 & 0.8977 & $0.98(0.76-1.26)$ & 0.9695 & $0.99(0.76-1.30)$ \\
\hline MR1 rs1052632 & $\mathrm{G} / \mathrm{A}$ & 0.271 & 0.259 & 0.7118 & $0.94(0.70-1.26)$ & 0.7854 & $0.96(0.71-1.30)$ \\
\hline TLR1 rs5743618 & $\mathrm{G} / \mathrm{T}$ & 0.402 & 0.407 & 0.8991 & $1.02(0.80-1.31)$ & 0.9359 & $1.01(0.78-1.32)$ \\
\hline$T L R 2$ rs111200466 & $23 \mathrm{bp}$ ins/del & 0.175 & 0.165 & 0.6813 & $0.93(0.68-1.29)$ & 0.5575 & $0.90(0.65-1.27)$ \\
\hline TLR10 rs11096957 & $\mathrm{T} / \mathrm{G}$ & 0.474 & 0.472 & 0.9504 & $0.99(0.78-1.27)$ & 0.7115 & $1.05(0.82-1.35)$ \\
\hline IFNG rs2430561 & $\mathrm{T} / \mathrm{A}$ & 0.464 & 0.442 & 0.4925 & $0.92(0.72-1.17)$ & 0.8409 & $1.02(0.79-1.32)$ \\
\hline TNF rs1800629 & $\mathrm{G} / \mathrm{A}$ & 0.138 & 0.091 & 0.01843 & $0.63(0.42-0.92)$ & 0.03643 & $0.64(0.43-0.97)$ \\
\hline \multicolumn{8}{|l|}{ Males } \\
\hline IRAK1 rs1059703 & $A / G$ & 0.192 & 0.242 & 0.4356 & $1.34(0.72-2.51)$ & 0.3563 & $1.34(0.72-2.51)$ \\
\hline FoxP3 rs2232365 & $\mathrm{C} / \mathrm{T}$ & 0.404 & 0.456 & 0.4353 & $1.24(0.74-2.07)$ & 0.4156 & $1.24(0.74-2.07)$ \\
\hline \multicolumn{8}{|l|}{ Females } \\
\hline IRAK1 rs1059703 & $A / G$ & 0.250 & 0.233 & 0.686 & $0.91(0.61-1.36)$ & 0.6544 & $0.91(0.61-1.36)$ \\
\hline
\end{tabular}

\section{Haplotype analysis}

Nine common haplotypes in the gene cluster TLR1-TLR6-TLR10, four in the gene $T L R 2$ and three in the gene VDR were identified at a frequency $\geq 1 \%$ by LD analysis (Fig. 1). The rs11466657-rs11096957-rs5743618-rs4833095-rs5743810 haplotype A-T-G-T-A of the gene cluster TLR1-TLR6-TLR10 was significantly higher in the TB group compared to the controls $(p=0.0485$; Table 3). However, after 10000 -fold permutation testing this haplotype lost its significance ( $p=$ 0.4463). In addition, marginal differences between cases and controls were observed for the haplotype A-T-G-T-G (rs11466657-rs11096957-rs5743618rs4833095-rs5743810) in the gene cluster TLR1-TLR6-TLR10 ( $\mathrm{p}=0.0688)$ and haplotypes ins-T and ins-C (rs111200466-rs3804099) in TLR2 ( $p=0.0732$ and $p=0.0987$, respectively). None of the remaining haplotypes were associated with the risk of pulmonary TB in this study (Table 3 ). 
Table 3

Haplotype frequencies and associations with pulmonary TB.

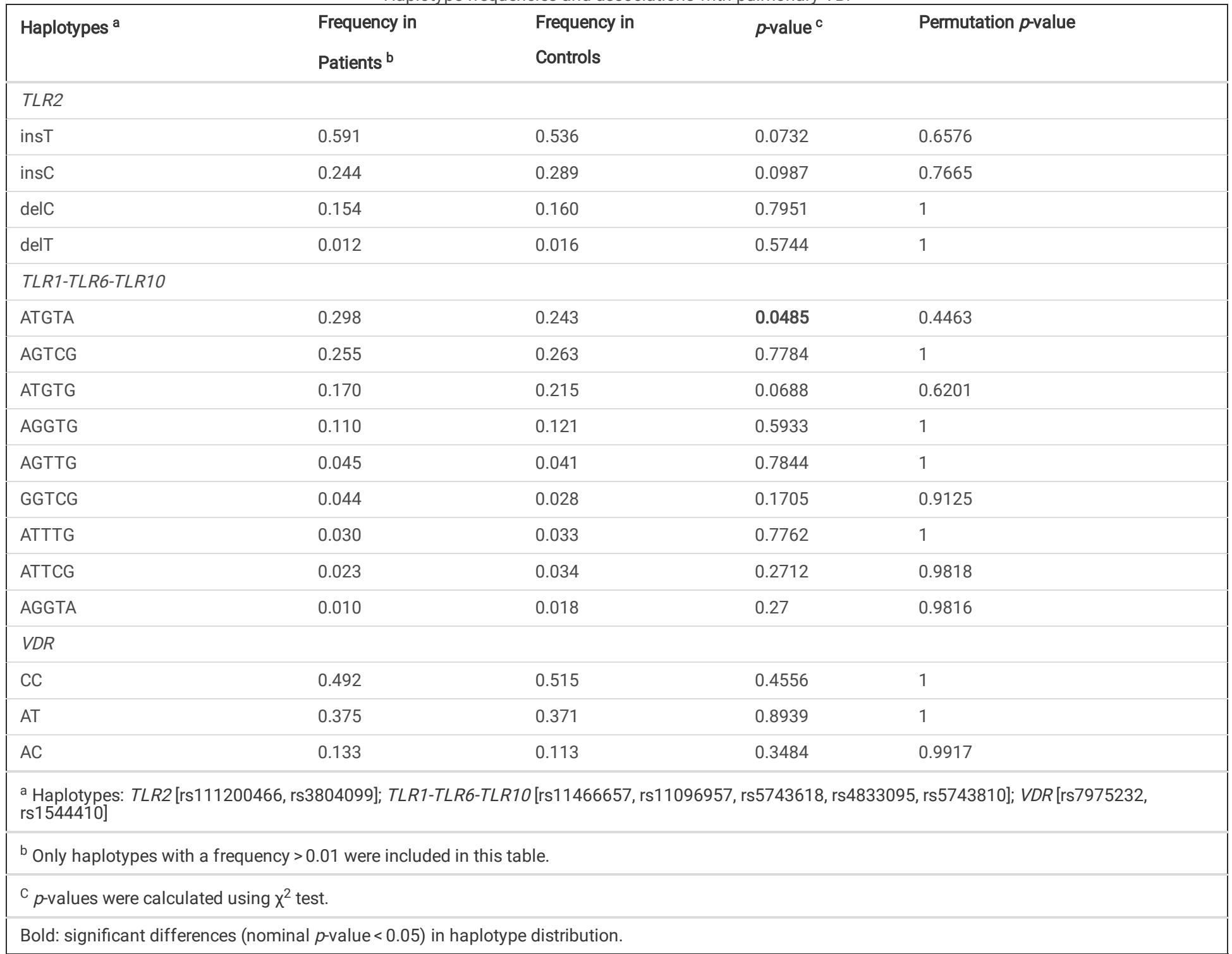

\section{Gene-gene interaction analysis}

Analysis of SNP-SNP combinations by logistic regression model revealed 59 significant (p-value < 0.05) genetic interactions (Additional file 3: Table S3), with the smallest $p$-values observed for the marker pairs TOLLIP rs3793964 - IRAK2 rs3844283 $(p=0.0025)$, TLR2 rs111200466 - TOLLIP rs5743899 ( $\mathrm{p}=0.0044)$, and TLR10 rs11096957 - TLR6 rs5743810 ( $p=0.0052)$. Although none of these associations exceeded the conservative Bonferroni-corrected threshold of $p-$ value $=4.69484 \mathrm{E}-05(0.05 / 1065)$, they suggest a potential role in conferring TB risk and therefore were pipelined into in depth genotype combination analysis. This resulted in 62 nominally significant associations ( $p$-value $<0.05$ for either logistic regression or Fisher exact test) out of 543 possible genotype combinations (Additional file 4: Table S4). The strongest association was observed between TB and the combination of TLR6 rs5743810 GA and TLR10 rs11096957 GT genotypes (Fisher exact test $p$-value $=1.5 \times 10^{-5}$; logistic regression $p$-value $=1.9 \times 10^{-5}$; Table 4). This association remained significant after Bonferroni correction $\left(p\right.$-value $\left.=0.05 /(1065+543)=3.11 \times 10^{-5}\right)$. Remarkably, the effect of this genotype combination on TB risk was much greater compared to the effects of individual genotypes (heterozygous model, $\mathrm{OR}=1.72, p=0.0042$ and $\mathrm{OR}=1.33, p=0.13$ for rs5743810 and rs 11096957 , respectively), implying strong synergistic interaction between them. None of the other genotype combinations passed Bonferroni correction. 
Table 4

Association of combined genotypes TLR6 rs 5743810 and TLR10 rs11096957 with pulmonary TB.

\begin{tabular}{|c|c|c|c|c|c|c|}
\hline \multicolumn{2}{|l|}{ Genotype } & \multicolumn{2}{|c|}{ Counts, $n(\%)$} & \multicolumn{2}{|c|}{ Association (p-value) } & \multirow[t]{2}{*}{ OR $(95 \% \mathrm{Cl})^{a}$} \\
\hline TLR6 rs5743810 & TLR10 rs11096957 & Controls & Patients & Fisher test & Logistic regression a & \\
\hline GG & TT & $58(23.8)$ & $56(21.1)$ & 0.56 & 0.83 & $0.94(0.60-1.47)$ \\
\hline GG & GT & $57(23.4)$ & $43(16.2)$ & 0.059 & 0.033 & $0.61(0.38-0.96)$ \\
\hline GG & GG & $19(7.8)$ & $16(6.0)$ & 0.55 & 0.59 & $0.80(0.37-1.72)$ \\
\hline GA & TT & $7(2.9)$ & $2(0.8)$ & 0.14 & 0.094 & $0.25(0.025-1.36)$ \\
\hline GA & GT & $42(17.2)$ & $91(34.3)$ & $1.5 \times 10^{-5}$ & $1.9 \times 10^{-5}$ & $2.48(1.62-3.85)$ \\
\hline GA & GG & $42(17.2)$ & $38(14.3)$ & 0.45 & 0.34 & $0.79(0.48-1.30)$ \\
\hline $\mathrm{AA}$ & TT & $17(7.0)$ & $18(6.8)$ & 0.94 & 0.86 & $0.91(0.43-1.91)$ \\
\hline AA & GT & $2(0.8)$ & $1(0.4)$ & 0.94 & 0.60 & $0.45(0.0077-8.86)$ \\
\hline \multicolumn{7}{|c|}{ a Adjusted for sex and age at recruitment. } \\
\hline
\end{tabular}

\section{Discussion}

In the present study, we applied a candidate-gene approach and tested the association of 14 polymorphisms in genes VDR, MR1, TLR1, TLR2, TLR10, SLC11A1, IL 1B, IL10, IFNG, TNF, IRAK1, and FOXP3 with the risk of pulmonary TB in Moldavian population. Although these genes are critical components of human immunity and their polymorphisms have been implicated in susceptibility/resistance to TB, we could not find convincing statistical evidence for their association with the risk of pulmonary TB in this study. A borderline association was revealed for polymorphism rs 1800629 in the $T N F$ gene only, but this did not survive corrections for multiple testing by Bonferroni method. Overall, the results presented here do not support a major role of the analyzed common variants in conferring susceptibility/resistance to pulmonary TB in Moldavian population.

The inability to reach significance level after Bonferroni correction may be explained by a fairly small sample size and inadequate statistical power to produce convincing associations for polymorphisms with low and moderate effects (with $\mathrm{OR}<1.5$ ). For this reason, we cannot completely rule out the possibility of true functional effects for variants with nominal associations, in particular for TNF rs 1800629 polymorphism. The TNF gene encodes a multifunctional proinflammatory cytokine TNF-a which is mainly produced by activated monocytes, macrophages and T-lymphocytes when stimulated by mycobacterial antigens. TNF- $a$ acts synergistically with IFN- $y$ to induce macrophages killing of M.tb [39]. In addition, TNF-a is involved in the recruitment of leukocytes to the site of infection and contributes to the formation of TB granuloma, preventing the spread of infection [39]. It is reported that treatment with TNF-a inhibitors leads to reactivation of latent TB infection, indicating TNF-a as a key cytokine towards resistance to M.tb [40]. SNP rs1800629 (-308G >A) is located within regulatory hotspot region and thus influences transcription critically $[41,42]$. The minor allele $A$ of rs 1800629 has been associated with increased expression of TNF and higher plasma levels of TNF-a [17]. In agreement with published functional studies, our results demonstrated a higher frequency of allele A in controls than in cases, suggesting its protective role against TB $(\mathrm{OR}=0.63)$. Similarly, allele A was protectively associated with TB in Colombian [16] and Mexican [18] populations. However, other genetic epidemiologic studies involving patient cohorts from various population groups, including Malawi [43], Iran [44], Indian [45], Cambodian [46], Chinese Han and Tibetan [47], did not confirm the above findings. The disparity in results across studies may be explained by certain factors such as inadequate sample sizes and differences in environmental, demographic, cultural, host genetic and bacterial characteristics of M.tb strains.

Additionally, a nominal yet suggestive association was demonstrated for haplotype A-T-G-T-A of the block rs11466657-rs11096957-rs5743618-rs4833095rs5743810 in the gene cluster TLR1-TLR6-TLR10. Genes TLR1, TLR6, and TLR10 are located in a 54-kb genomic region on chromosome 4p14 and encode proteins that share a high degree of homology in their amino acid sequences. All three genes belong to the TLR2 subfamily of TLRs, which plays a critical role in the early recognition of M.tb and subsequent activation of immune responses [48]. Individual polymorphisms and haplotypes within the TLR10-TLR1-TLR6 locus have been associated with altered susceptibility to infectious disease, including mycobacterial infections of leprosy and TB [11, 49, 50, 51, 52]. Unfortunately, different sets of SNPs used in this and in other studies complicate direct comparisons of the results. Even so, the identified haplotype A-T-G-T-A and, more generally, variations in genes $T L R 10, T L R 1$ and $T L R 6$ could be a promising replication target for future studies in larger cohorts.

Genetic interactions are thought to underlie susceptibility/resistance to TB $[5,53]$, so they could explain some of the missing heritability in this study. Therefore, we also analyzed the impact of allele combinations on TB risk. The strongest evidence for interaction in our data was between SNPs rs 5743810 and rs11096957 located in genes TLR6 and TLR10, respectively. Interestingly, the two SNPs showed no or only weak effect on TB susceptibility when evaluated alone, indicating a synergetic mechanism of $T L R 6$ rs5743810 and TLR10 rs11096957 in conferring risk for pulmonary TB.

Interaction between these SNPs is biologically plausible. Firstly, TLRs are the key players in the host defense against infections. Specifically, TLR6 functionally interacts with TLR2 to mediate the cellular response to bacterial lipoproteins and activate the NF-KB pathway and inflammatory events through MyD88 dependent signaling $[10,48,52]$. TLR10 has also the ability to form heterodimers with TLR2, but its specific ligands have not yet been identified and its downstream signaling is not fully understood. It is thought to act through both MyD88 dependent and independent signaling pathways with mainly inhibitory effects on inflammation [10]. The genetic interaction between TLR6 and TLR10 observed in this study may reflect their mutual functional contribution to M.tb 
recognition and subsequent downstream signaling (Fig. 2). Secondly, the investigated SNPs in TLR6 and TLR10 genes had been shown before to be of functional significance. In fact, the two SNPs are non-synonymous variants located in the extracellular (leucine-rich repeat) domains of the encoded proteins. Both ex vivo and in vitro experiments showed that SNPs rs5743810 (Ser249Pro) and rs11096957 (Asn241His) may influence pro-inflammatory cytokine production in humans $[10,54,55]$. In addition, polymorphism rs5743810 was observed to affect NF-KB signaling activity, thereby modulating inflammatory responses [56]. Furthermore, the two polymorphisms have been associated with several immune-related pathologic conditions and infectious diseases, including TB $[11,51,52,57]$. These data support the relevance of additive interaction between SNPs rs5743810 and rs 11096957 and suggest a molecular mechanism by which genetic variations in TLR6 and TLR10 genes might increase susceptibility to TB (Fig. 2).

The present study is the first to identify an interaction between TLR6 rs5743810 and TLR10 rs11096957 gene variants in TB risk. Further larger case-control studies followed by functional tests are warranted to validate this initial finding and eventually translate it into clinical practice. Particularly, given the high spread of the combined TLR6 rs5743810 GA - TLR10 rs11096957 GT genotype in European population ( 15-20\%), it might be used as a novel predictive biomarker for identification of individuals at high risk for active TB disease.

Some limitations of our study deserve consideration. Firstly, it was limited in power to detect the weak association signals, so our negative results should be treated with caution. Secondly, healthy controls were not tested for latent M.tb infection, and therefore it was not possible to discriminate between TB-infected and TB-uninfected individuals. However, as mentioned in the materials and methods, the controls were recruited from TB-communities where they were permanently exposed to TB and therefore are expected to be infected. Third, the number of polymorphisms in the immune system genes analyzed was limited. Given their key role in TB pathogenesis, additional TB risk variants, haplotypes and allele combinations may possibly exist.

A potential limitation of this study is a significant deviation from HWE of the interacting SNP TLR10 rs11096957 (Asn241His) in the controls. Such deviations can result from genotyping errors, recruiting biases, natural selection or be simply a chance. We excluded genotyping errors by random re-genotyping of $T L R 10$ rs 11096957 in $21 \%$ of samples. Also, our study design prevented the recruitment of any relatives. The natural selection could be the reason for the observed deviation, which may be supported by the evidence of similar heterozygosity deficiency in Toscani in Italy, TSI (HWE $p$-value $=0.02 ; 1000$ Genomes Project data) and considerable intra-population variation of SNP TLR10 rs 11096957 within Europe (the allele G frequency range: $32.4 \%$ in British, GBR - $48.6 \%$ in Iberian population, IBS; 1000 Genomes Project data). Moreover, the recruitment of healthy controls from TB communities used in this project may have a similar kind of impact for the locus TLR10 like natural selection, contributing to the deficiency of rs 11096957 heterozygotes. Taken together, these arguments justify the inclusion of TLR10 rs11096957 in association tests.

\section{Conclusion}

In the current study, we replicated a significant association between rs1800629 in the TNF gene and pulmonary TB. Also, haplotypes in the gene cluster TLR1TLR6-TLR10 showed a weak yet suggestive association. Further, we provide convincing statistical evidence for a synergistic effect between polymorphic variants in the TLR6 and TLR10 genes on TB risk, which further supports the importance of TLR signaling in the genetic basis of TB and the concept of genetic interactions accounting for missing heritability. Further studies are warranted to validate the interaction between $T L R 6$ and $T L R 10$ and to elucidate its role in TB risk, which would be beneficial for human health.

\section{Abbreviations}

TB: tuberculosis

M.tb: Mycobacterium tuberculosis

AIDS: acquired immune deficiency syndrome

TLR1: toll like receptor 1 (gene)

TLR2: toll like receptor 2 (gene)

TLR6: toll like receptor 6 (gene)

TLR8: toll like receptor 8 (gene)

TLR9: toll like receptor 9 (gene)

TLR10: toll like receptor 10 (gene)

IFNG: interferon gamma (gene)

TNF: tumor necrosis factor alpha (gene)

IRAK1: interleukin-1 receptor-associated kinase 1 (gene)

IL 1B: interleukin 1 beta (gene)

IL 10: interleukin 10 (gene) 
NRAMP1: Natural Resistance-Associated Macrophage Protein 1 (gene)

SLC11A1: solute carrier 11 member 1 (gene)

FOXP3: Forkhead box protein P3 (gene)

VDR: Vitamin D receptor (gene)

MR1: Major histocompatibility complex class I-related gene protein (gene)

HIV: human immunodeficiency viruses

BCG: bacillus Calmette-Guérin

EDTA: ethylenediaminetetraacetic acid

HWE: Hardy-Weinberg Equilibrium

SNP: single nucleotide polymorphism

MALDI-TOF: matrix-assisted laser desorption/ionization time-of-flight

PCR: polymerase chain reaction

RFLP: restriction fragment length polymorphism

SSPs: sequence-specific primers

MAF: minor allele frequency

OR: odds ratio

Cl: confidence interval

LD: linkage disequilibrium

NF-KB: nuclear factor kappa-light-chain-enhancer of activated B cells

MyD88: myeloid differentiation primary response 88

CEU: Utah residents with Northern and Western European ancestry

FIN: Finnish in Finland

GBR: British from England and Scotland

IBS: Iberian populations in Spain

TSI: Toscani in Italia

\section{Declarations}

\section{Ethics approval and consent to participate}

The study was approved by the Research Ethic Committee of the Institute of Phthisiopneumology (Republic of Moldova) and was conducted in accordance with the Declaration of Helsinki. All participants gave their written informed consent.

\section{Consent for publication}

All authors consent to the publication of this manuscript.

\section{Availability of data and materials}

The datasets supporting the conclusions of this article are included within the article and its additional files. The raw data (i.e., sample-linked data on the sex, age and genotypes) analyzed during the current study are available from the corresponding author on reasonable request.

\section{Competing interests}

The authors declare that they have no competing interests.

\section{Funding}


The study was supported by the Academy of Sciences of Moldova and Hannover Unified Biobank. Alexander Varzari was sponsored by the Alexander von Humboldt Foundation.

\section{Authors' contributions}

AV wrote the manuscript. AV and IVD designed the study and analyzed the data. ET designed the study and collected the data. AV and HG performed the experiments. TI had primary responsibility for the final content. All authors read and approved the final manuscript.

\section{Acknowledgements}

We thank all the patients and control subjects for participating in this study and providing blood samples.

\section{Author information}

\section{Affiliations}

Laboratory of Human Genetics, Chiril Draganiuc Institute of Phthisiopneumology, Kishinev, Republic of Moldova

Alexander Varzari and Elena Tudor

Hannover Unified Biobank, Hannover Medical School, Hannover, Germany

Thomas Illig and Alexander Varzari

Department of Human Genetics, Hannover Medical School, Hannover, Germany

Thomas Illig

Laboratory of Functional Genomics, Timiryazev Institute of Plant Physiology Russian Academy of Sciences, Moscow, Russia

Igor V. Deyneko

Research Unit of Molecular Epidemiology, Institute of Epidemiology, Helmholtz Zentrum München Research Center for Environmental Health, Neuherberg, Germany

Harald Grallert

Corresponding author

Correspondence to Alexander Varzari

\section{References}

1. Lawn SD, Zumla Al. Tuberculosis. Lancet 2011;378(9785):57-72.

2. Orlova M, Schurr E. Human Genomics of Mycobacterium tuberculosis Infection and Disease. Curr Genet Med Rep. 2017;5(3):125-131.

3. Stein CM, Sausville L, Wejse C, Sobota RS, Zetola NM, Hill PC, Boom WH, Scott WK, Sirugo G, Williams SM. Genomics of human pulmonary tuberculosis: from genes to pathways. Curr Genet Med Rep. 2017;5(4):149-166.

4. Cai L, Li Z, Guan X, Cai K, Wang L, Liu J, Tong Y. The Research Progress of Host Genes and Tuberculosis Susceptibility. Oxid Med Cell Longev. 2019;2019:9273056.

5. Abel L, Fellay J, Haas DW, Schurr E, Srikrishna G, Urbanowski M, Chaturvedi N, Srinivasan S, Johnson DH, Bishai WR. Genetics of human susceptibility to active and latent tuberculosis: present knowledge and future perspectives. Lancet Infect Dis. 2018;18(3):e64-e75.

6. Varzari A, Deyneko IV, Vladei I, Grallert H, Schieck M, Tudor E, Illig T. Genetic variation in TLR pathway and the risk of pulmonary tuberculosis in a Moldavian population. Infect Genet Evol. 2019;68:84-90.

7. Uciechowski P, Imhoff H, Lange C, Meyer CG, Browne EN, Kirsten DK, Schröder AK, Schaaf B, Al-Lahham A, Reinert RR, Reiling N, Haase H, Hatzmann A, Fleischer D, Heussen N, Kleines M, Rink L. Susceptibility to tuberculosis is associated with TLR1 polymorphisms resulting in a lack of TLR1 cell surface expression. J Leukoc Biol. 2011;90(2):377-88.

8. Naderi M, Hashemi M, Mirshekari H, Bahari G, Taheri M. Toll-like Receptor 1 Polymorphisms Increased the Risk of Pulmonary Tuberculosis in an Iranian Population Sample. Biomed Environ Sci. 2016;29(11):825-828.

9. Velez DR, Wejse C, Stryjewski ME, Abbate E, Hulme WF, Myers JL, Estevan R, Patillo SG, Olesen R, Tacconelli A, Sirugo G, Gilbert JR, Hamilton CD, Scott WK. Variants in toll-like receptors 2 and 9 influence susceptibility to pulmonary tuberculosis in Caucasians, African-Americans, and West Africans. Hum Genet. 2010;127(1):65-73.

10. Oosting M, Cheng SC, Bolscher JM, Vestering-Stenger R, Plantinga TS, Verschueren IC, Arts P, Garritsen A, van Eenennaam H, Sturm P, Kullberg BJ, Hoischen A, Adema GJ, van der Meer JW, Netea MG, Joosten LA. Human TLR10 is an anti-inflammatory pattern-recognition receptor. Proc Natl Acad Sci U S A. 2014;111(42):E4478-84. 
11. Bulat-Kardum LJ, Etokebe GE, Lederer P, Balen S, Dembic Z. Genetic Polymorphisms in the Toll-like Receptor 10, Interleukin (IL)17A and IL17F Genes Differently Affect the Risk for Tuberculosis in Croatian Population. Scand J Immunol. 2015;82(1):63-9.

12. Sampath V, Mulrooney NP, Garland JS, He J, Patel AL, Cohen JD, Simpson PM, Hines RN. Toll-like receptor genetic variants are associated with Gramnegative infections in VLBW infants. J Perinatol. 2013;33(10):772-7.

13. Hu CY, Zhang XA, Meyer CG, Thye T, Liu W, Cao WC. Polymorphism of X-linked CD40 ligand gene associated with pulmonary tuberculosis in the Han Chinese population. Genes Immun. 2015;16(6):399-404.

14. Pravica V, Perrey C, Stevens A, Lee JH, Hutchinson IV. A single nucleotide polymorphism in the first intron of the human IFN-g gene: absolute correlation with a polymorphic CA microsatellite marker of high IFN-g production. Hum Immunol 2000;61:863 - 6.

15. Wei Z, Wenhao S, Yuanyuan M, Yang L, Daming Z, Jiangchun X, Jijun J. A single nucleotide polymorphism in the interferon- $Y$ gene (IFNG +874 T/A) is associated with susceptibility to tuberculosis. Oncotarget. 2017;8(31):50415-50429.

16. Correa PA, Gomez LM, Cadena J, Anaya JM. Autoimmunity and tuberculosis. Opposite association with TNF polymorphism. J Rheumatol. 2005;32(2):219-24.

17. Elahi MM, Asotra K, Matata BM, Mastana SS. Tumor necrosis factor alpha -308 gene locus promoter polymorphism: an analysis of association with health and disease. Biochim Biophys Acta. 2009;1792(3):163-72.

18. de Arellano ITR, Lara CS, Espíndola LMT, de Jesús Castillejós López M, Prado AJ, Cruz RV, Camacho JLG, Patiño N, Bojórquez JDR, Suck MLT. Exposure to biomass smoke, cigarettes, and alcohol modifies the association between tumour necrosis factor (-308G/A, -238G/A) polymorphisms and tuberculosis in Mexican carriers. Arch Med Sci. 2020;16(3):672-681.

19. Hall NB, Igo RP Jr, Malone LL, Truitt B, Schnell A, Tao L, Okware B, Nsereko M, Chervenak K, Lancioni C, Hawn TR, Mayanja-Kizza H, Joloba ML, Boom WH, Stein CM; Tuberculosis Research Unit (TBRU). Polymorphisms in TICAM2 and IL1B are associated with TB. Genes Immun. 2015;16(2):127-133.

20. Turner DM, Williams DM, Sankaran D, Lazarus M, Sinnott PJ, Hutchinson IV. An investigation of polymorphism in the interleukin-10 genepromoter. Eur J Immunogenet. 1997;24:1-8.

21. Areeshi MY, Mandal RK, Dar SA, Jawed A, Wahid M, Lohani M, Panda AK, Mishra BN, Akhter N, Haque S. IL-10 -1082 A>G (rs1800896) polymorphism confers susceptibility to pulmonary tuberculosis in Caucasians but not in Asians and Africans: a meta-analysis. Biosci Rep. 2017;37(5):BSR20170240.

22. Frĕdin MB, Rudko AA, Kolokolova OV, Ondar EA, Strelis AK, Puzyrev VP. A comparative analysis of tuberculosis susceptibility genetic make-up in Tuvinians and Russians. Mol Biol (Mosk). 2006;40(2):252-62.

23. Yuan L, Ke Z, Guo Y, Xi X, Luo Z. NRAMP1 D543N and INT4 polymorphisms in susceptibility to pulmonary tuberculosis: A meta-analysis. Infect Genet Evol. 2017;54:91-97.

24. Beiranvand E, Abediankenari S, Khani S, Hosseini HM, Zeinali S, Beiranvand B, Goudarzi M, Seyedjavadi SS. G allele at -924 A > G position of FoxP3 gene promoter as a risk factor for tuberculosis. BMC Infect Dis. 2017;17(1):673.

25. Uitterlinden AG, Fang Y, Van Meurs JB, Pols HA, Van Leeuwen JP. Genetics and biology of vitamin D receptor polymorphisms. Gene. 2004;338(2):143-56.

26. Xu X, Shen M. Associations between vitamin D receptor genetic variants and tuberculosis: a meta-analysis. Innate Immun. 2019;25(5):305-313.

27. Chen C, Liu Q, Zhu L, Yang H, Lu W. Vitamin D receptor gene polymorphisms on the risk of tuberculosis, a meta-analysis of 29 case-control studies. PLoS One. 2013;8(12):e83843.

28. Seshadri C, Thuong NT, Mai NT, Bang ND, Chau TT, Lewinsohn DM, Thwaites GE, Dunstan SJ, Hawn TR. A polymorphism in human MR1 is associated with mRNA expression and susceptibility to tuberculosis. Genes Immun. 2017;18(1):8-14.

29. World Health Organization. Global tuberculosis report 2019. 2019.

30. Miller SA, Dykes DD, Polesky HF. A simple salting out procedure for extracting DNA from human nucleated cells. Nucleic Acids Res. $1988 ; 16(3): 1215$.

31. Tahara T, Arisawa T, Wang F, Shibata T, Nakamura M, Sakata M, Hirata I, Nakano H. Toll-like receptor 2 -196 to 174del polymorphism influences the susceptibility of Japanese people to gastric cancer. Cancer Sci. 2007;98(11):1790-4.

32. Leoratti FM, Farias L, Alves FP, Suarez-Mútis MC, Coura JR, Kalil J, Camargo EP, Moraes SL, Ramasawmy R. Variants in the toll-like receptor signaling pathway and clinical outcomes of malaria. J Infect Dis. 2008;198(5):772-80.

33. Chang CC, Chow CC, Tellier LC, Vattikuti S, Purcell SM, Lee JJ. Second-generation PLINK: rising to the challenge of larger and richer datasets. Gigascience. $2015 ; 4: 7$

34. Barrett JC, Fry B, Maller J, Daly MJ. Haploview: analysis and visualization of LD and haplotype maps. Bioinformatics. 2005;21(2):263-5.

35. Solé X, Guinó E, Valls J, Iniesta R, Moreno V. SNPStats: a web tool for the analysis of association studies. Bioinformatics. 2006;22(15):1928-9.

36. Varzari A, Deyneko IV, Tudor E, Turcan S. Polymorphisms of glutathione S-transferase and methylenetetrahydrofolate reductase genes in Moldavian patients with ulcerative colitis: Genotype-phenotype correlation. Meta Gene. 2015;7:76-82.

37. Varzari A, Tudor E, Bodrug N, Corloteanu A, Axentii E, Deyneko IV. Age-Specific Association of CCL5 Gene Polymorphism with Pulmonary Tuberculosis: A Case-Control Study. Genet Test Mol Biomarkers. 2018;22(5):281-287.

38. Skol AD, Scott LJ, Abecasis GR, Boehnke M. Joint analysis is more efficient than replication-based analysis for two-stage genome-wide association studies. Nat Genet. 2006;38(2):209-13.

39. Cavalcanti YV, Brelaz MC, Neves JK, Ferraz JC, Pereira VR. Role of TNF-Alpha, IFN-Gamma, and IL-10 in the Development of Pulmonary Tuberculosis. Pulm Med. 2012;2012:745483.

40. Long R, Gardam M. Tumour necrosis factor-alpha inhibitors and the reactivation of latent tuberculosis infection. CMAJ. 2003;168(9):1153-6. 
41. Wilson AG, Symons JA, McDowell TL, McDevitt HO, Duff GW. Effects of a polymorphism in the human tumor necrosis factor alpha promoter on transcriptional activation. Proc Natl Acad Sci U S A. 1997;94(7):3195-9.

42. Ponomarenko M, Rasskazov D, Chadaeva I, Sharypova E, Drachkova I, Oshchepkov D, Ponomarenko P, Savinkova L, Oshchepkova E, Nazarenko M, Kolchanov N. Candidate SNP Markers of Atherogenesis Significantly Shifting the Affinity of TATA-Binding Protein for Human Gene Promoters show stabilizing Natural Selection as a Sum of Neutral Drift Accelerating Atherogenesis and Directional Natural Selection Slowing It. Int J Mol Sci. 2020; 21(3):

43. Fitness J, Floyd S, Warndorff DK, Sichali L, Malema S, Crampin AC, Fine PE, Hill AV. Large-scale candidate gene study of tuberculosis susceptibility in the Karonga district of northern Malawi. Am J Trop Med Hyg. 2004;71(3):341-9.

44. Jafari M, Nasiri MR, Sanaei R, Anoosheh S, Farnia P, Sepanjnia A, Tajik N. The NRAMP1, VDR, TNF-a, ICAM1, TLR2 and TLR4 gene polymorphisms in Iranian patients with pulmonary tuberculosis: A case-control study. Infect Genet Evol. 2016;39:92-98.

45. Selvaraj P, Sriram U, Mathan Kurian S, Reetha AM, Narayanan PR. Tumour necrosis factor alpha (-238 and -308) and beta gene polymorphisms in pulmonary tuberculosis: haplotype analysis with HLA-A, B and DR genes. Tuberculosis (Edinb). 2001;81(5-6):335-41.

46. Delgado JC, Baena A, Thim S, Goldfeld AE. Ethnic-specific genetic associations with pulmonary tuberculosis. J Infect Dis. 2002;186(10):1463-8.

47. Wu S, Wang MG, Wang Y, He JQ. Polymorphisms of cytokine genes and tuberculosis in two independent studies. Sci Rep. $2019 ; 9(1): 2507$.

48. Casanova JL, Abel L, Quintana-Murci L. Human TLRs and IL-1Rs in host defense: natural insights from evolutionary, epidemiological, and clinical genetics. Annu Rev Immunol. 2011;29:447-91.

49. Ma X, Liu Y, Gowen BB, Graviss EA, Clark AG, Musser JM. Full-exon resequencing reveals toll-like receptor variants contribute to human susceptibility to tuberculosis disease. PLoS One. 2007;2(12):e1318.

50. Dittrich N, Berrocal-Almanza LC, Thada S, Goyal S, Slevogt H, Sumanlatha G, Hussain A, Sur S, Burkert S, Oh DY, Valluri V, Schumann RR, Conrad ML. Tolllike receptor 1 variations influence susceptibility and immune response to Mycobacterium tuberculosis. Tuberculosis (Edinb). 2015;95(3):328-35.

51. Barletta-Naveca RH, Naveca FG, de Almeida VA, Porto JIR, da Silva GAV, Ogusku MM, Sadahiro A, Ramasawmy R, Boechat AL. Toll-Like Receptor-1 SingleNucleotide Polymorphism 1805T/G Is Associated with Predisposition to Multibacillary Tuberculosis. Front Immunol. 2018;9:1455.

52. Mukherjee S, Huda S, Sinha Babu SP. Toll-like receptor polymorphism in host immune response to infectious diseases: A review. Scand J Immunol. 2019;90(1):e12771.

53. de Wit E, van der Merwe L, van Helden PD, Hoal EG. Gene-gene interaction between tuberculosis candidate genes in a South African population. Mamm Genome. 2011;22(1-2):100-10.

54. Kormann MS, Depner M, Hartl D, Klopp N, Illig T, Adamski J, Vogelberg C, Weiland SK, von Mutius E, Kabesch M. Toll-like receptor heterodimer variants protect from childhood asthma. J Allergy Clin Immunol. 2008;122(1):86-92, 92.e1-8.

55. Randhawa AK, Shey MS, Keyser A, Peixoto B, Wells RD, de Kock M, Lerumo L, Hughes J, Hussey G, Hawkridge A, Kaplan G, Hanekom WA, Hawn TR; South African Tuberculosis Vaccine Initiative Team. Association of human TLR1 and TLR6 deficiency with altered immune responses to BCG vaccination in South African infants. PLoS Pathog. 2011;7(8):e1002174.

56. Shey MS, Randhawa AK, Bowmaker M, Smith E, Scriba TJ, de Kock M, Mahomed H, Hussey G, Hawn TR, Hanekom WA. Single nucleotide polymorphisms in toll-like receptor 6 are associated with altered lipopeptide- and mycobacteria-induced interleukin-6 secretion. Genes Immun. 2010;11(7):561-72.

57. Schurz H, Daya M, Möller M, Hoal EG, Salie M. TLR1, 2, 4, 6 and 9 Variants Associated with Tuberculosis Susceptibility: A Systematic Review and MetaAnalysis. PLoS One. 2015;10(10):e0139711.

\section{Figures}

TLR1-TLR6-TLR10

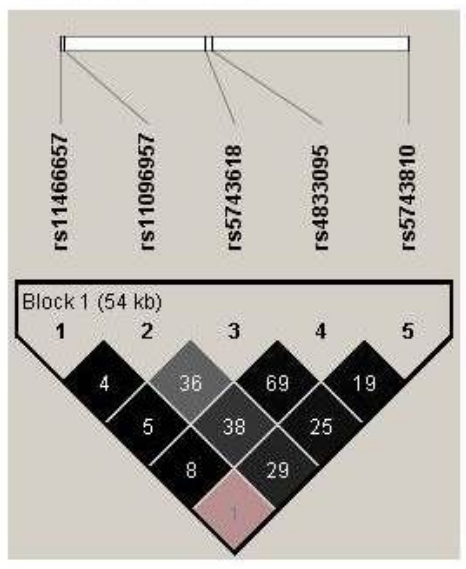

TLR2

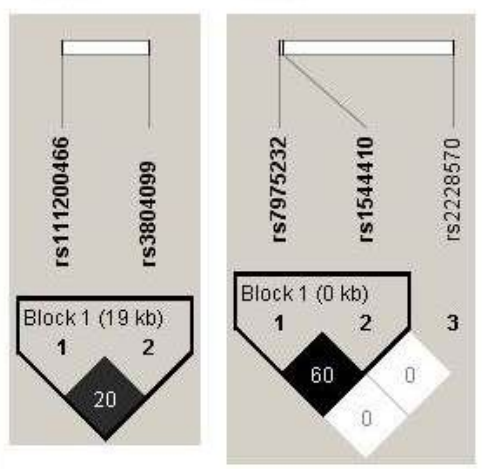

Figure 1

Linkage disequilibrium (LD) plots of TLR2, VDR and TLR1-TLR6-TLR10 polymorphisms in the combined group of cases and controls. The colours of the squares represent $D^{\prime}$ values, with black being $D^{\prime}=1$, and white $D^{\prime}=0$. The 2 values $(\%)$ are indicated on the squares (no value $=100 \%$ ). 


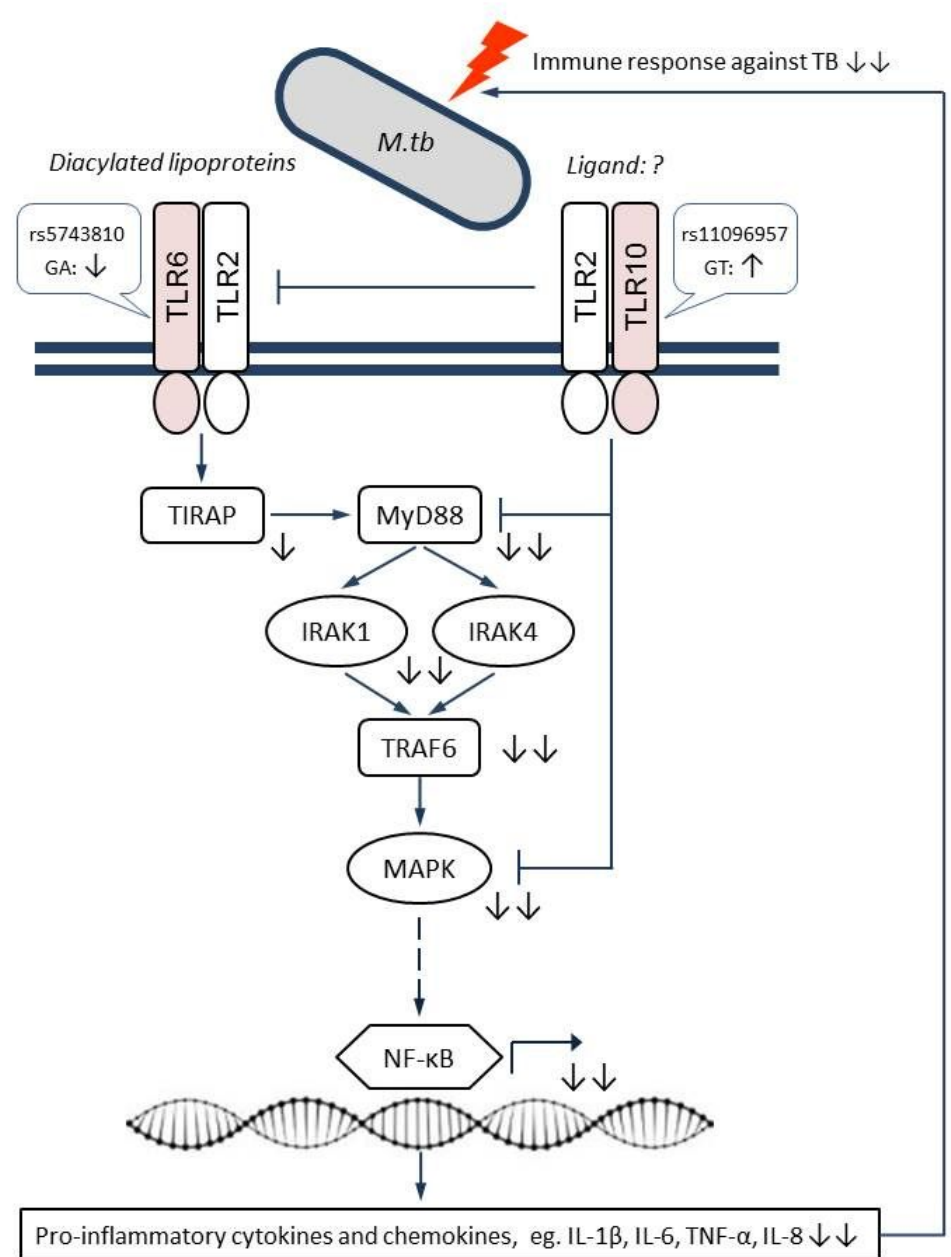

\section{Figure 2}

Schematic representation of the proposed epistatic/synergistic interaction between SNPs TLR6 rs5743810 and TLR10 rs11096957 in conferring susceptibility to TB based on the present results. Symbols indicate the following: sharp arrow - positive interaction; blunt-pointed arrow - negative interaction; solid line direct interaction; dashed line - indirect interaction; question mark - unknown ligand partner; $(\uparrow)$ - up-regulation/activation; $(\downarrow)$ - down-regulation/suppression. TLR6 and TLR10 have largely opposite effects on the immune response, with TLR10 mainly having a suppressive function. Simultaneous suppression of TLR6 signaling and activation of TLR10 signaling caused by genetic variations may result in decreased pro-inflammatory responses against M.tb, and thus increase the risk of TB. Figure adapted from Oosting et al. 2014.

\section{Supplementary Files}

This is a list of supplementary files associated with this preprint. Click to download.

- Additionalfile1.docx

- Additionalfile2.docx

- Additionalfile3.xlsx

- Additionalfile4.xlsx 